\title{
Features and factors of demographic dynamics in the Kyrgyz Republic
}

\author{
Alexandre A. Avdeev ${ }^{1,2}$, Irina A. Troitskaya ${ }^{1}$ \\ 1 Lomonosov Moscow State University, Moscow, 119991, Russia \\ 2 Université Paris 1 Panthéon Sorbonne, Paris, 75013, France
}

Received 9 April 2021 • Accepted 10 May 2021 • Published 30 June 2021

Citation: Avdeev AA, Troitskaya IA (2021) Features and factors of demographic dynamics in the Kyrgyz Republic. Population and Economics 5(2): 29-54. https://doi.org/10.3897/popecon.5.e67183

\begin{abstract}
The article analyzes the current demographic situation in the Kyrgyz Republic, as well as the main components of population dynamics: natural population growth, internal mobility and international migration. Basing on census data, current statistics and population surveys, the authors assess the impact of demographic processes in the republic on the age and sex structure and the rate of ageing of the Kyrgyz population, as well as on population settlement and its concentration in the centres of attraction of internal migrants, and the urbanization process.

Analysis of demographic dynamics in the Kyrgyz Republic has shown a number of interrelated problems and challenges caused by the rapid growth of the population and changes in its age structure, requiring urgent social and economic policy measures. Key of the revealed problems are mass departure of the population in the working age, especially young people (labour migration), growth of population of retirement age, and uneven population settlement with concentration around the two largest urban agglomerations of the republic, the cities of Bishkek and Osh.
\end{abstract}

\section{Keywords}

Kyrgyz Republic, demographic situation, natural population growth, international migration, internal population mobility, population ageing, resettlement, urbanization

JEL codes: J10, J11

\section{Introduction}

It can be said without exaggeration that the demographic situation in the Kyrgyz Republic is documented and studied better than in other Central Asian countries that were once part of the USSR. Despite the difficulties of political and economic development, indepen- 
dent Kyrgyzstan managed not only to conduct two general censuses (in 1999 and 2009) and maintain the effectiveness of the current population statistics, but also to ensure the production and publication of detailed demographic statistics both in traditional yearbooks and in digital form. In addition, a number of national population studies were conducted in the republic: Demographic and Health Survey (DHS) in 1997 and 2012 and the Multiple Indicator Cluster Survey (MICS) in 1995, 2005-2006, 2014, and $2018^{1}$.

Opportunities for a detailed analysis of the demographic development of Kyrgyzstan on the basis of such a rich collection of empirical data were materialized by an international team of researchers in two thorough studies published in 2004 and 2011 (Population... 2004; Population... 2011). In addition, it should be mentioned that the problems of the population of the Kyrgyz Republic were analyzed in the broader context of the prospects for demographic development in the post-Soviet space (Sievert, Zakharov et al. 2011).

Over the years following these publications, many events have taken place in the social, economic, and political life of the Kyrgyz Republic, the observation horizon has expanded, and new data have appeared. The geopolitical context has also changed; in particular, in 2015 the Kyrgyz Republic became a member of the Eurasian Economic Union, which created new conditions for international migration within the framework of the freedom of labour force, capital, goods, and services exchange. In this regard, it seems important to us to draw attention to the most serious demographic challenges that the Kyrgyz Republic will undoubtedly face in the foreseeable future.

Since the format of this publication does not allow covering all aspects of the demographic situation, we will limit ourselves to considering only those parameters of demographic dynamics in the Kyrgyz Republic that are directly related to the need to make strategic decisions in the field of social and economic policy and indicate problems that cannot be solved on the basis of existing institutions and social infrastructure (education, health care, social protection).

After the collapse of the USSR, the Kyrgyz Republic received, on the one hand, an established system of administrative management, a developed infrastructure of public health, education, vocational training, a road transport network and an energy supply system, which were largely created through transfers between the union republics, and on the other - almost complete absence of any significant full-cycle production facilities. If, under the conditions of an integrated economy and a unitary system of government of the Soviet Union, local risks in the economic and demographic sphere were distributed among all Union republics, then after the collapse of the USSR, the young independent states of Central Asia found themselves face to face with their own problems, including those associated with the rapid population growth and high fertility. The population, accustomed to the Soviet system of social protection, was not ready to give up free education and health care, guaranteed employment, social housing, while maintenance, not even development, of social infrastructure required appropriate funding, which could not be provided by the unbalanced real sector of the economy.

This contradictory situation gave rise to social tension, which was localized mainly in large cities, which became centres of attraction for migration flows from rural areas, where the fertility level and population growth were especially high. In Soviet times, the migration of the surplus rural population was blocked using administrative methods. The only ways of leaving the countryside, apart from marital migrations, were organized labour migration (organizational recruitment, etc.)

1 Individual DHS data for 1997 and 2012 are available to researchers on the DHS Programme website https://dhsprogram.com/data/available-datasets.cfm; individual MICS data for 2005-2006, 2014, and 2018, as well as standard summary reports for all years, are freely available on the UNICEF website https://mics.unicef.org/surveys 
or departure to study at higher and secondary specialized educational institutions. Thus, the exodus from rural areas was largely due to the acquisition of professional qualifications that were in demand in the labour market. After the collapse of the Soviet system and the provision of guarantees of free movement (at least within the borders of national territories), surplus population from the countryside rushed to the cities, increasing competition for resources as well as social tensions.

We can say the international migration is that the valve reducing the pressure of the population on resources. On the one hand, the departure of the population abroad to work (labour migration) enables reducing tension on the labour market and even raising the standard of living due to remittances, but on the other hand, this is a decrease in the resources for replenishing the budget of social protection funds (health care, education, pensions), in whatever form they may exist. In addition, if the national economy does not provide more or less complete coverage of the consumer needs of the population, money received from abroad (labour income of migrants) will be spent on the purchase of imported goods, that is, it will eventually return to the countries of origin. In these conditions, it seems obvious that in the countries of Central Asia, including the Kyrgyz Republic, the most serious demographic challenges that require a political response are rapid growth of the population, changes in its socio-demographic structure, in particular the proportion and number of the working age population, internal and external migration of the population, the description and analysis of which is the aim of this study.

\section{Population dynamics in Kyrgyzstan}

From the middle of the $20^{\text {th }}$ century to this day, the population of the Kyrgyz Republic has tripled; over the past 5 years (from January 1, 2015, to January 1, 2021), it has increased by almost 710 thousand people, or 12\% (Fig. 1). In 2020, despite the COVID-19 pandemic, due to natural growth alone, the population of the republic increased by 118 thousand people.

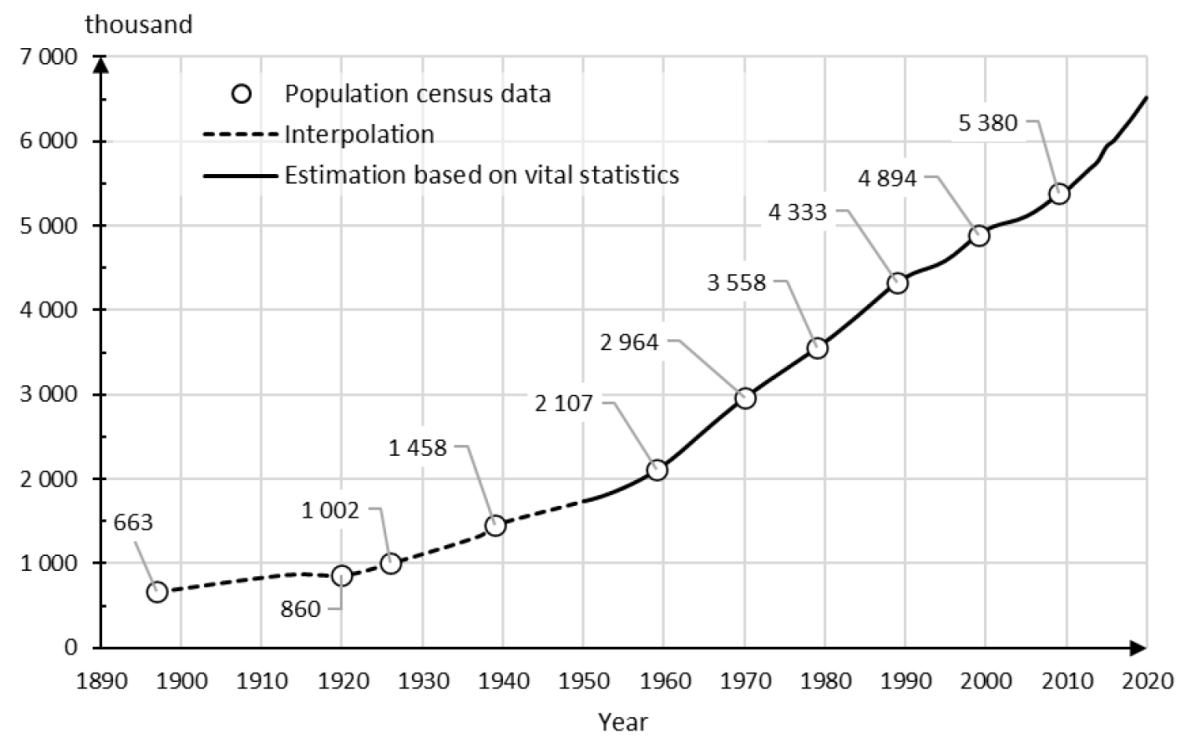

Fig. 1. Dynamics of the population of Kyrgyzstan, 1897-2020. Source: Population Censuses of the Russian Empire, Russian Federation, USSR, and Kyrgyz Republic; National Statistical Committee of the Kyrgyz Republic (hereinafter - NSC KR, http://www.stat.kg/ru/ ) 
According to the latest UN probabilistic forecast, the population growth of the Kyrgyz Republic will continue at least until the end of this century (Fig. 2). The fastest growth will be observed in the next 30 years, and by 2050 the population will exceed 9 million, that is, an increase of 50\% compared to 2020 . Then the growth will slow down, and in the next 30 years the population of the republic will grow by only 1.5 million people (compared to the previous version, the current forecast has been revised upwards).

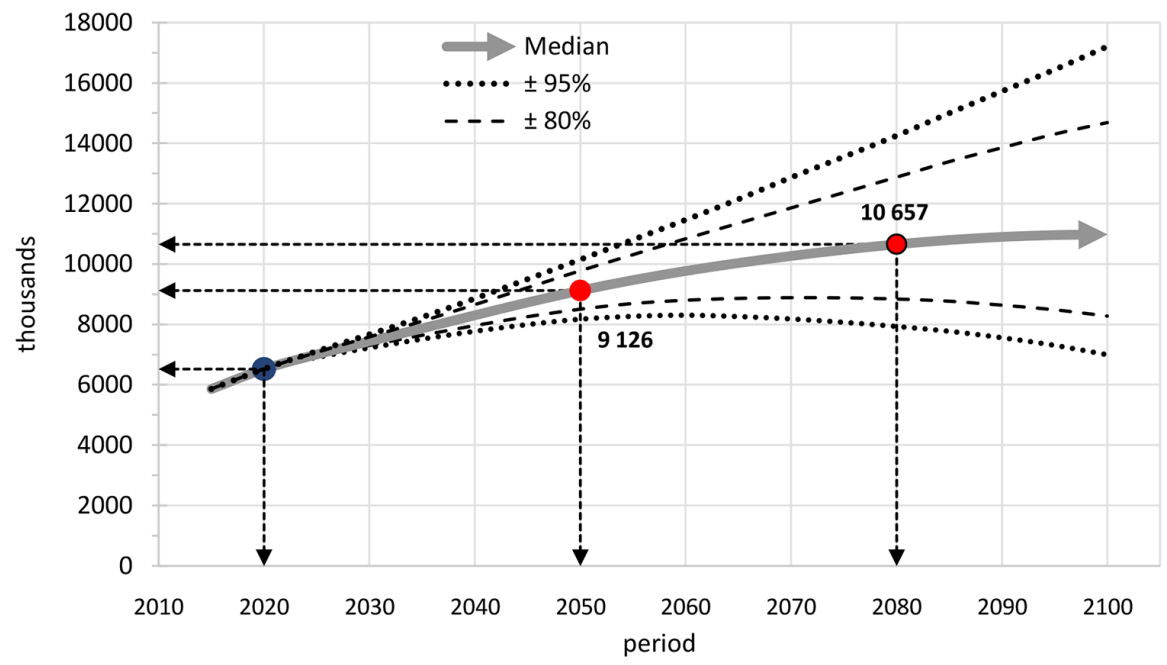

Fig. 2. Prospects for the growth of the population of the Kyrgyz Republic until the end of the $21^{\text {st }}$ century. Source: (United Nations 2019). Note: The dashed lines outline the intervals for the expected population size estimated with a given probability. At that, with a probability of $95 \%$, it can be expected that in 2080 the population will be in the range from 7.9 to 14.2 million people, with a probability of $80 \%$ it will be in the range from 8.8 to 12.8 million. The wider the interval, the more likely it is that the expected population size will fall within that interval.

Despite the rapid population growth, the Kyrgyz Republic will remain the most sparsely populated state in Central Asia, and in the foreseeable future, the difference in the population of Kyrgyzstan and its closest neighbours will only increase (Fig. 3). As a result, one can expect an increase in demographic pressure (primarily through migration) from Uzbekistan and Tajikistan, where the living space is already quite saturated, as well as a reduction in opportunities for labour migration of Kyrgyz residents to Kazakhstan, where the need for labour imports may decrease due to the growth of their own population.

Such a rapid population growth in Kyrgyzstan poses a significant threat of lack of living space. Taking into account the fact that due to the particular geographical conditions, the area of the territory suitable for comfortable living and conducting economic activity in the republic is extremely limited; a further increase in population density will create an additional burden on the environment.

Formally, of the entire geographically and climatically comfortable territory (less than 1500 meters above sea level), 32\% is located in the Jalal-Abad oblast, $25 \%$ - in the Chuy oblast, $17 \%$ - in the Batken, and 14\% - in the Osh oblast; the remaining 10\% are in Talas oblast, while the territories of Naryn and Issyk-Kul oblasts lie entirely at an altitude of more than 1,500 meters above sea level (Fig. 4). 


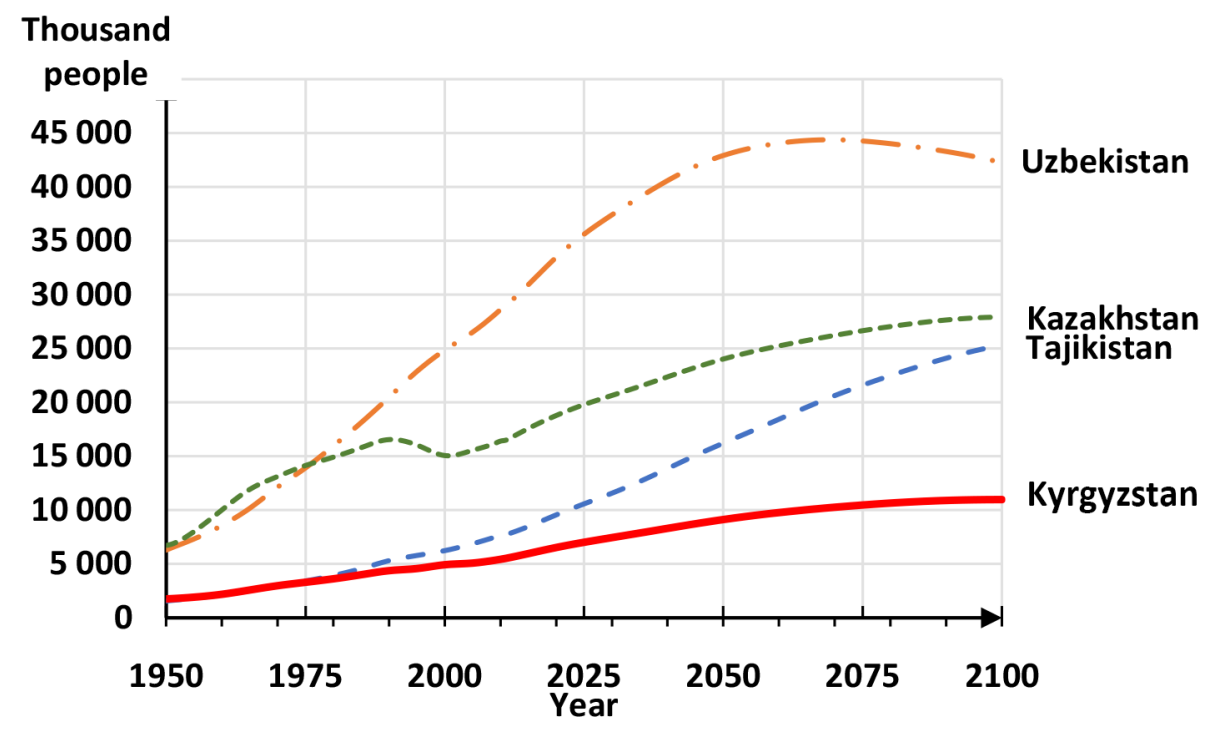

Fig. 3. Population dynamics of the Kyrgyz Republic and neighbouring states. Source: (United Nations 2019).

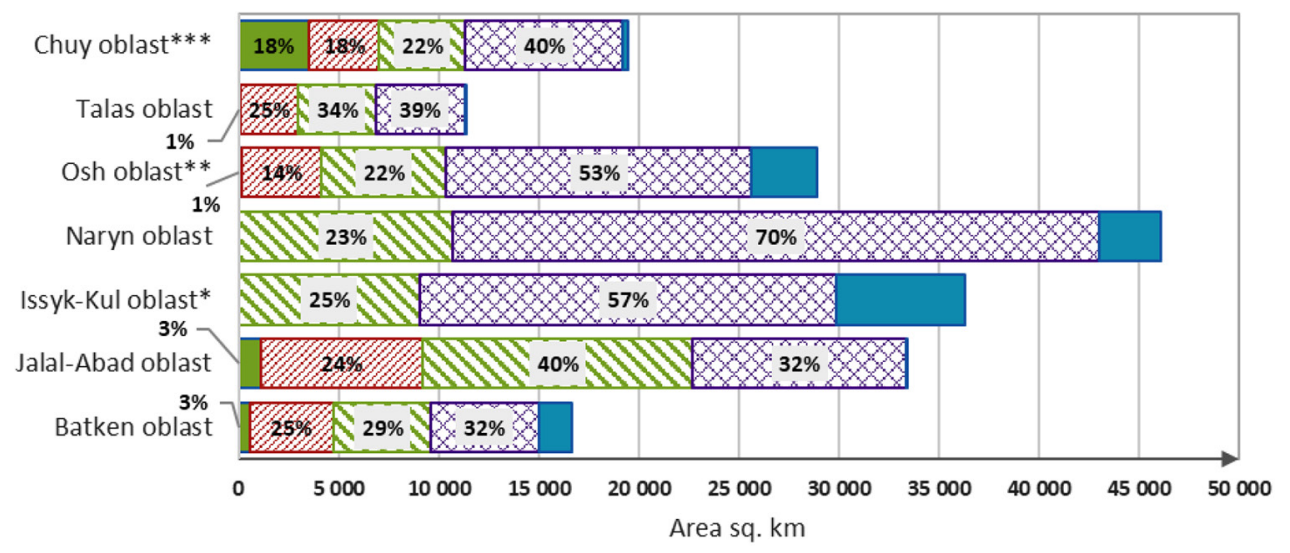

Altitude above sea level $\square<750 \quad$ - 750-1500 $₫ 1500-2500 \quad \square 2500-4000 \quad \square>=4000$

Fig. 4. Distribution of regions of the Kyrgyz Republic by height and area. Source: NSC KR. Notes: ${ }^{\star}$ excluding the area of Lake Issyk-Kul (6236 sq. km at an altitude of 1607 meters above sea level); ${ }^{* *}$ including the area of the city of republican significance Osh; ${ }^{* *}$ - including the area of the capital, the city of republican significance Bishkek

Due to the geographical features of Kyrgyzstan, its population is concentrated around two poles: the capital region, which includes the city of Bishkek and the adjacent administrative districts of the Chuy oblast, and along the Osh-Jalal-Abad axis, in the regions of the «fertile crescent» bordering the Fergana Valley. Over the past 5 years, from 2015 to 2020, the concentration of the population in both territories has increased. The population of the cities of Bishkek, Osh and the seven districts bordering the Fergana Valley currently represents $53 \%$ of the population of Kyrgyzstan, although the size of these areas in total does not exceed $12 \%$ of the country's total area. 


\section{Factors and components of population dynamics in the Kyrgyz Republic}

\subsection{Natural growth}

The rapid population growth in the Kyrgyz Republic is due to the peculiarities of the historical change in the regime of population reproduction (Fig. 5). The import of the newest medical technologies, the development of sanitary infrastructure and the availability of qualified medical care have led to a rapid decrease in mortality. At the same time, the preservation of the traditional way of life, especially in rural areas, combined with measures to support families with children (free education and medical care, benefits for large families) have slowed down the fertility decline.

The rapid population growth did not create problems for the Kyrgyz Soviet Socialist Republic within the USSR, where social and economic risks were redistributed among all members of the union. This policy provided funding for the social sphere (health care, education, and culture), as well as guarantees of employment and social protection of the population (old-age pensions, affordable medical care). After the collapse of the USSR, the solution of the stated tasks became the responsibility of the government of the Kyrgyz Republic, and the rapid demographic growth became a national problem and a potential source of threat to the development of the national economy and the living standards of the population.

The growth in the population of the Kyrgyz Republic is fully ensured by the natural component, that is, the excess of the number of births over the number of deaths. On the contrary, the net balance of international migration in Kyrgyzstan has always been negative (more people left the republic than arrived for permanent residence), with the exception of the 1960 s, when a stream of specialists was sent to the republic to work on the construction of large industrial and infrastructure facilities.

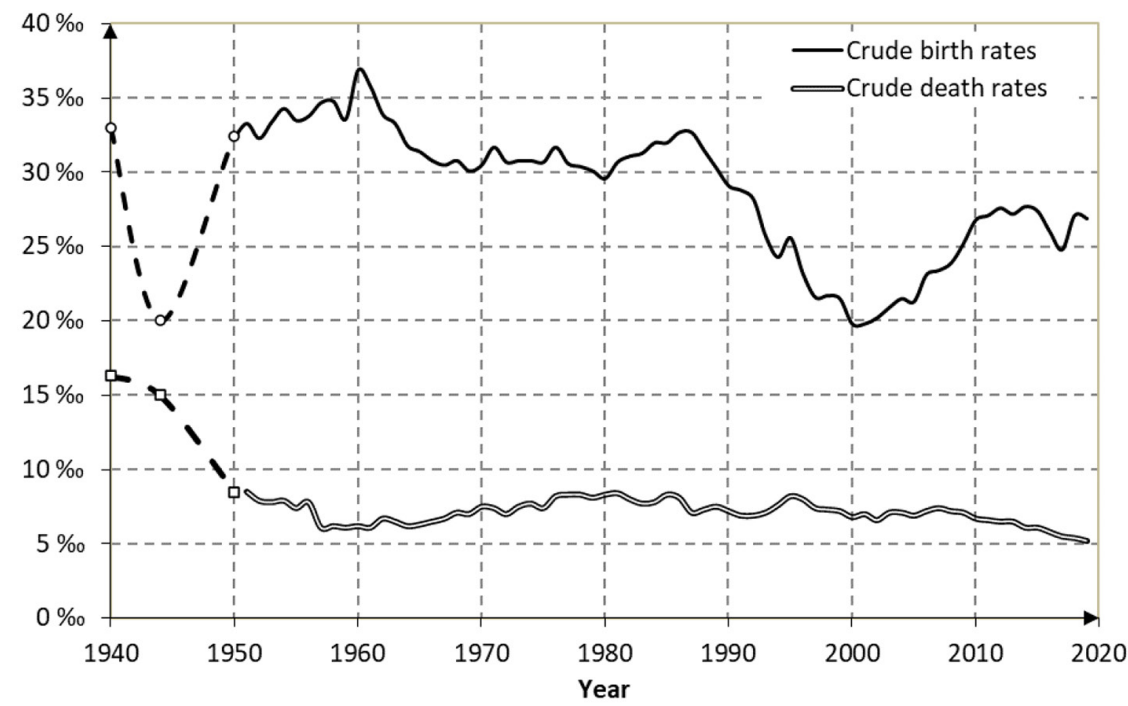

Fig. 5. Fertility and mortality dynamics in Kyrgyzstan, 1940-2020 (demographic transition). Source: Statistical Committee of the Kyrgyz Republic (http://www.stat.kg/ru/); authors' calculations based on (Population... 1975; Population... 1989; Demographic yearbook... 1990). 
In turn, the natural increase in the population of the Kyrgyz Republic is provided by a large number of births (Fig. 6). According to the current UN forecast, the number of births will be rising at least until 2020. This growth will take place both due to the peculiarities of the age structure of the population of the Kyrgyz Republic (the growing share of women of reproductive age in the total population), and due to the preservation of the ideal of a family with 3-4 children.

It is important to note that an increase in the number of births means, on the one hand, an increase in the need for medical care related to the course of pregnancy, childbirth and the postpartum period, and on the other, an increase in the needs of a specific group of the population, namely, infants and young children, adolescents and youth.

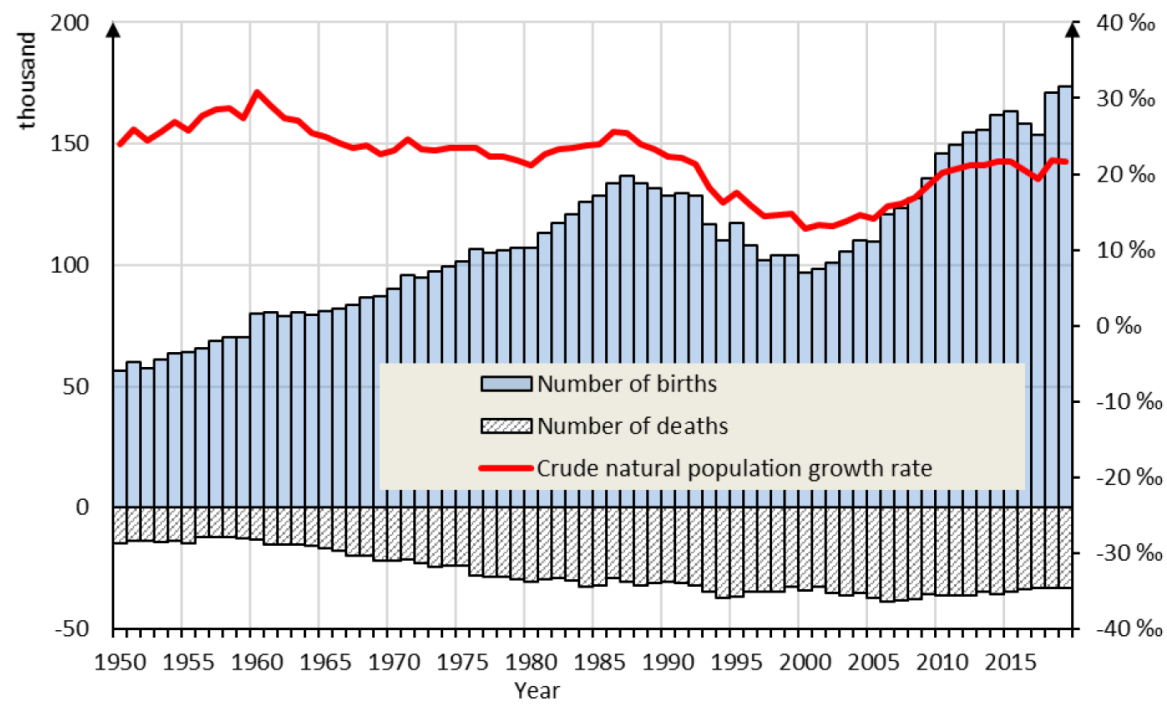

Fig. 6. Dynamics of the rate of natural growth (per thousand population), the number of births and deaths in Kyrgyzstan, 1950-2020. Source: NSC KR, Devision database.

\subsection{Migration}

Migration and natural growth as components of population dynamics have a different effect on the age structure of the population. If a high rate of natural population growth increases the population in childhood and adolescence, then migration, as a rule, concerns the population of working age. Unfortunately, the available data of official statistics of migration (registration at the place of stay) in the Kyrgyz Republic do not enable giving a quantitative assessment of the direction of regional migration flows and the composition of migrants by sex and age.

Usually, when the population grows in conditions of limited living space, migration plays the role of a safety valve, allowing to reduce the pressure of the population on resources. As already mentioned, the migration outflow of the population is historically characteristic of the Kyrgyz Republic. The magnitude of the migration outflow in Kyrgyzstan reached the highest values in the 1990s, when, in connection with the collapse of the USSR, ethnic groups whose historical homeland received a new political status left the country (Russians, Ukrainians, Germans, etc.; see, for example, (Dzhusupbekov and Shamshibaev 2017: 72-73)). Then the volume of migration (migration turnover) and the migration balance decreased, reaching minimum sizes in the 2010s (Fig. 7). 


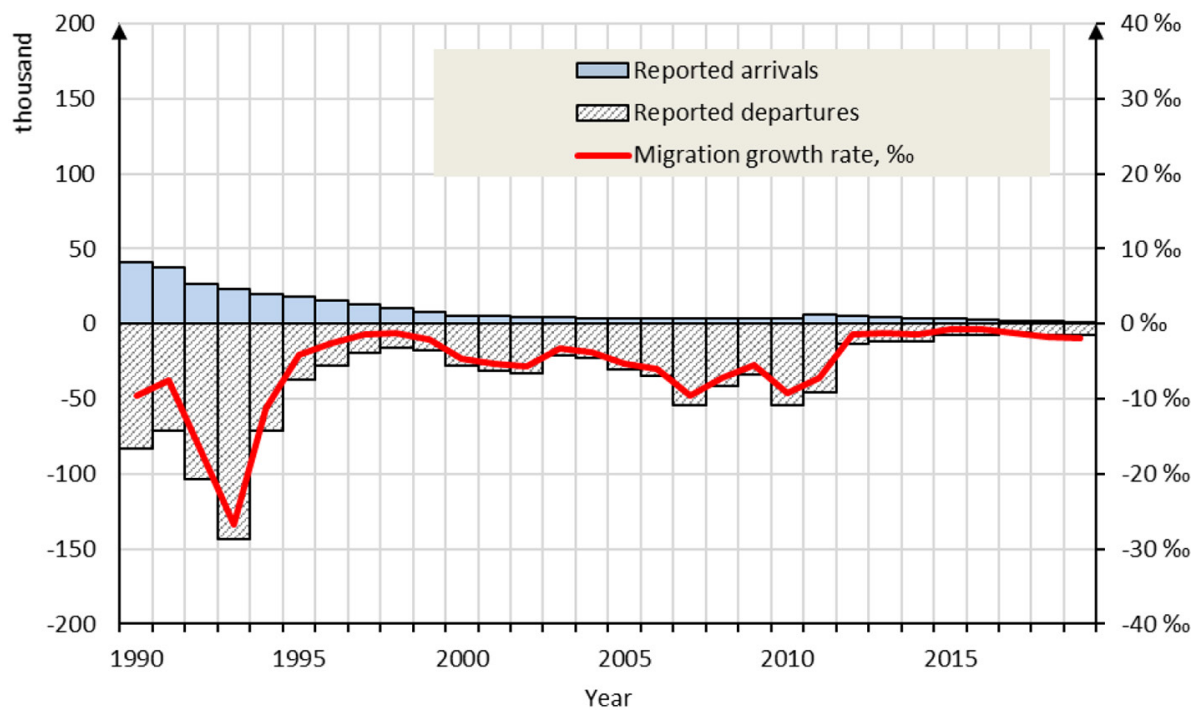

Fig. 7. Dynamics of migration growth and the number of arrivals and departures in Kyrgyzstan, 1950-2020. Source: NSC KR, Devision database.

High migration activity has had and still has a noticeable impact on the change in the ethnic structure of the population of the Kyrgyz Republic (Fig. 8). According to the data of post-war population censuses, the share of the ethnic Kyrgyz people in the Kirghiz SSR ranged from $40.5 \%$ in 1959 to $52.4 \%$ in 1989 , and their number in the period from 1959 to 1989 increased from 2.06 to 4.26 million, that is, more than doubled. The second largest ethnic group was the Russians, whose share varied from 30\% in 1959 to 26\% in 1989, and the number increased from 624 to 917 thousand people. After the collapse of the USSR, a mass departure of Russians and representatives of other European ethnic groups from the republic began. In general, according to the assessment of the NSC KR between 1989 and 2017 the number of ethnic Russians decreased to 357 thousand, that is, by 2.5 times, and now they make up less than $6 \%$ of the republic's population, while the share of the ethnic Kyrgyz people has grown to $73.2 \%$, and their number - to 4.5 million.

The second largest ethnic group in the republic was the Uzbeks, whose number increased between 1989 and 2017 from 550 to almost 900 thousand people, and their share in the population of the republic increased from 12.9 to $14.6 \%$ over the same period. In addition, over the years of independence in the republic, the number of ethnic groups in Central Asia has noticeably increased, by almost 2 times: Dungan (from 37 to 69 thousand), Uighurs (from 36.7 to 56 thousand) and Tajiks (from 33.5 up to 53.8 thousand).

The dynamics of the population size depends not only on the balance of migration, but also on the level of natural increase, which is much higher among the ethnic groups of Central Asia. Nevertheless, it was migration that was the main factor in such a significant decrease in the number and share of representatives of European ethnic groups in the population of the Kyrgyz Republic. The ethnic component of external migration in the Kyrgyz Republic retains its importance to this day. Thus, among the people who left the republic over the past 5 years, ethnic Russians make up $40 \%$, and in the structure of the migration balance, they accounted for $51 \%$. Note that over the past 10 years, the balance of external migration for all major ethnic groups has been negative. 


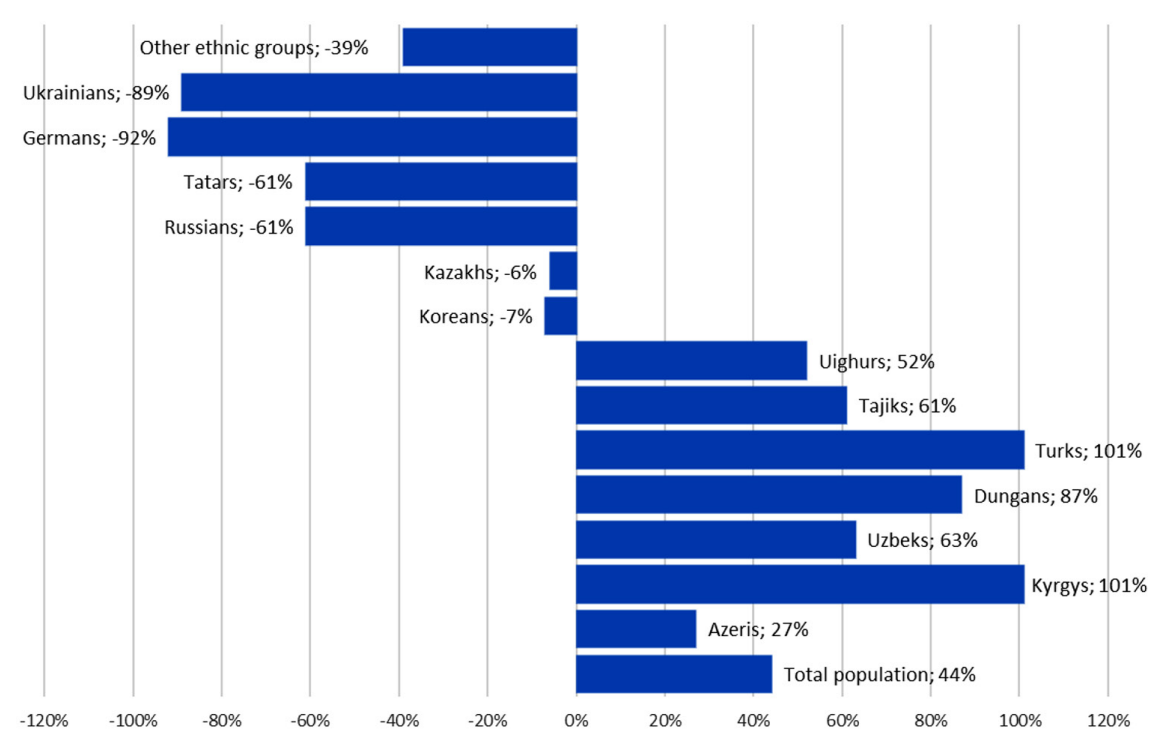

Fig. 8. Change in the size of the main ethnic groups of the population of the Kyrgyz Republic between 1989 and 2017. Source: authors' calculations based on population censuses and current estimates of NSC KR

\section{The problem of quantifying the real volume of migration exchange between the Kyrgyz Republic and foreign countries}

The decrease in the volume and balance of external migration of Kyrgyzstan is, in a sense, a statistical artefact. The fact is that the regulatory tables published by the Statistical Committee of the Kyrgyz Republic (section 5 of the Demographic Yearbooks, tables 5.1-5.5) include only data on migrants who had arrived and left for permanent residence, but say nothing about the number of so-called labour migrants, that is, about those who had left the country for temporary work, and those who had come to the Kyrgyz Republic in order to earn money. Therefore, estimates of the volume of external migration based only on the data of the Statistical Committee of the Kyrgyz Republic are significantly underestimated, and the conclusions are overly optimistic (Sheyitov 2018: 42).

Since the Treaty on the Eurasian Economic Union (EAEU) created conditions for the free movement of people and capital between participating countries, it is possible to establish the fact of migration (in the broadest sense of the word) based on the registration of a migrant in the country of arrival. Let us consider, for example, the Russian Federation, which was and remains the main direction of migration of citizens of the Kyrgyz Republic. According to the registration data of the Ministry of Internal Affairs of the Russian Federation in 2019, over one million citizens of the Kyrgyz Republic were registered in Russia (1,055 thousand). Of this number, 584 thousand (55\%) were accepted for primary registration, including 454 thousand indicating «work» as the motive. In addition, another 456 thousand resumed registration, but in this case, there is no indication of the motive (table 1). In 2020, due to anti-epidemic measures, the number of primary registrations decreased by 2.3 times, but the upward trend in the number of resumed ones has continued, although has slowed down. 
In addition to registration at the place of stay, visiting foreigners and persons without citizenship can be registered at the place of residence in the Russian Federation. In the period 2017-2019, the number of registrations of the Kyrgyz Republic citizens at the place of residence in the Russian Federation was stable and amounted to 15-16 thousand per year.

Table 1. Number of acts of migration registration at the place of stay of visitors from the Kyrgyz Republic by the migration service of the Ministry of Internal Affairs of the Russian Federation, 2010-2020.

\begin{tabular}{cccc}
\hline \multirow{2}{*}{ Year } & Total number & \multicolumn{2}{c}{ among them } \\
\cline { 3 - 4 } & of registrations & primary registrations & resumed registrations \\
\hline 2010 & 521008 & 431554 & 86676 \\
2011 & 618414 & 520091 & 94250 \\
2012 & 586035 & 480426 & 93272 \\
2013 & 728074 & 582523 & 129373 \\
2014 & 784084 & 605816 & 158252 \\
2015 & 929742 & 678852 & 233010 \\
2016 & 826640 & 474058 & 335136 \\
2017 & 879575 & 479940 & 384770 \\
2018 & 876795 & 456835 & 404182 \\
2019 & 1055458 & 583717 & 455657 \\
2020 & 737929 & 247467 & 475413
\end{tabular}

Source: Ministry of Internal Affairs of the Russian Federation, Statistical information on the migration situation https://xn--blaew.xn--plai/Deljatelnost/statistics (hereinafter - the Ministry of Internal Affairs of the Russian Federation)

The number of citizens of the Kyrgyz Republic removed from the migration register for the same period amounted to almost 849.4 thousand people. Thus, in 2019, taking into account labour migration, leaving for study, etc., the volume of real migration turnover of the Kyrgyz Republic with Russia alone was close to 2 million people (Fig. 9), and the balance of labour migration in this direction amounted to at least 200 thousand people, that is, it was almost 1.5 times more than the value of natural population growth and $20 \%$ more than the number of births.

Setting aside 2020, when the dynamics of migration flows, in all likelihood, were disrupted due to the COVID-19 pandemic, a tendency for an increase in the volume of labour migration (migration turnover) can be noted between the Kyrgyz Republic and the Russian Federation with a decrease in the balance. This enables hoping for the stabilization of migration exchange between the two countries (the number of arrivals is coming close to the number of departures). At the same time, one cannot ignore the fact that the migration balance accumulated over 4 years amounted to almost 1.3 million people, that is, about $17 \%$ of the total population of the republic, or 28\% of the population of working age (aged 15-65 years). In other words, the Kyrgyz Republic exports almost a third of its own labour force (workers) to Russia alone.

The practice of accounting for expatriates as part of the current or even permanent population should be taken into account when analyzing and assessing changes in the territorial structure of the population, since, as already noted, in 2017-2020, the cumulated balance of labour migration to Russia alone was comparable to the population of the Jalal-Abad oblast or the city of Bishkek. 


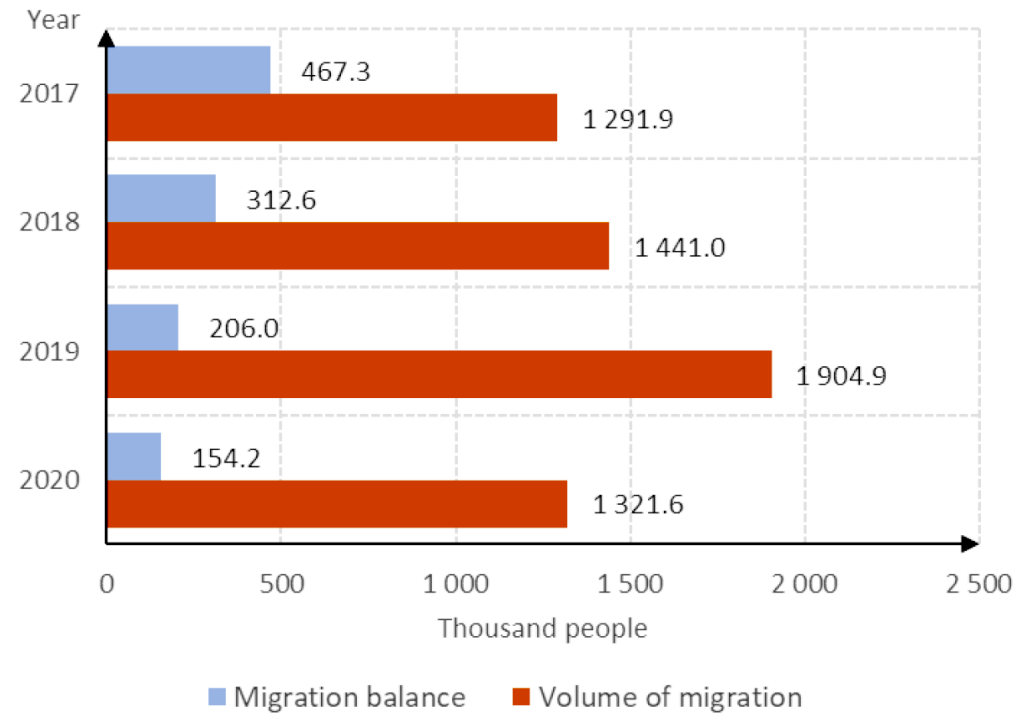

Fig. 9. Estimation of the volume and balance of labour migration between the Kyrgyz Republic and the Russian Federation based on data on registration of migration, 2017-2020. Source: Ministry of Internal Affairs of the Russian Federation

It should be noted that the data on flows of international migrants published by Rosstat should be treated with some caution. At present, the peculiarities of statistical registration of migrants in the Russian Federation are such that the number of arrivals may be underestimated, and the number of departures may be overestimated, and this will affect the estimates of both the migration turnover and the balance of migration. Starting from 2010 Rosstat has included in the current registration of migration persons temporarily registered for a period of 9 months or more, and several short-term registrations (up to 3 months) during the year are not accounted for in statistics, even if the total stay of a migrant in Russia exceeds 9 months. At the end of the period of migration registration in Russia, all international migrants are automatically considered to have left for the country of their previous residence, although this does not always mean their departure from Russia and return to their homeland (Chudinovskikh and Stepanova 2020).

\section{Population structure by sex and age}

By demographic standards, the population of Kyrgyzstan is "young». Half of the republic's residents are under 24 years old (as of January 1, 2020, the median age was 24.06 years), preschool children (under 7 years old) represent $17 \%$ of the republic's population, and about $21 \%$ are schoolchildren (7-17 years old).

In the age-sex pyramid of the modern population of the Kyrgyz Republic one can clearly see the three "demographic waves», emerged due to the historical events of the $20^{\text {th }}$ century (Fig. 10).

It is also easy to see two features of deformation of the population pyramid of the Kyrgyz Republic, which should be taken into account when planning development. 


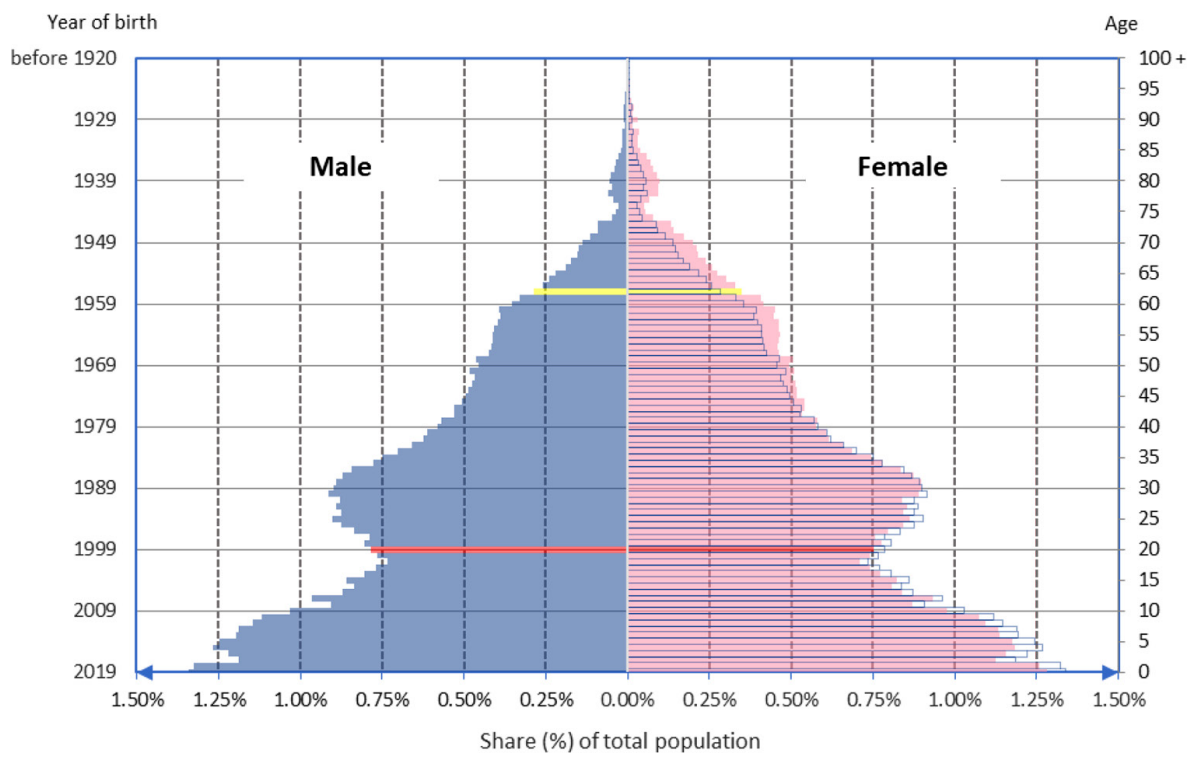

Fig. 10. Population structure of the Kyrgyz Republic by sex and age as of January 1, 2020 (urban and rural population). Source: NSC KR.

Firstly, this is a constant period of wave propagation, equal to about 30 years or the length of one generation. The first wave arose in connection with a decrease in the fertility rate during the Great Patriotic War (1941-1945), which in turn led to a decrease in the number of births in the second half of the 1960s, when a small generation of «children of war» entered an active reproductive age. The peak of the second wave was at the end of the 1980s, when the number of births increased both due to the multiplicity of the generation of mothers born in the early 1960s, and due to the measures introduced in the USSR in 1985-1987 to support young families. The third wave, which peaks at the end of the 2010s, is the children of those born at the turn of the 1990s and the grandchildren of those born in the early 1960s.

Secondly, it is a tendency towards a decrease in the wave amplitude (the quantitative ratio between the peaks). Thus, the ratio between the size of the generation of those born between 1989 and 1959 is approximately two to one, which corresponds to an average of 4 births per woman of the generation born in 1959. The ratio of generations born in 2019 and 1989 is just over 1.4, which corresponds to an average of 2.8-3 births per woman born in 1989.

From the above-mentioned, we can conclude that due to the peculiarities of the age structure, the dynamics of the population of the Kyrgyz Republic in many respects will be undulating at least until the end of the $21^{\text {st }}$ century. All other things being equal, the amplitude and frequency of demographic waves may vary slightly under the influence of changes in reproductive behaviour. A decrease in the birth rate, if any, can lead to amortization of the amplitude of the demographic wave, and a lengthening of the family formation cycle (an increase in the average age of motherhood) will affect the length of the wave period. When planning development, it is necessary to take into account the inevitability of a demographic wave with peaks in the late 2040s and 2070s. The demographic wave will have the greatest influence on the turnover of the labour force in the labour market and on the "demographic dividend», the concept of which ultimately boils down to the quantitative ratio of the producing and consuming population, that is, to the demographic burden on the population of working age (dependency ratio). 
Population growth in the process of demographic transition is inevitably associated with a change in the age structure of the population. The evolution of the age structure goes through certain stages: rejuvenation of the population (an increase in the proportion of children and young people due to a decrease in mortality in childhood), a "demographic window» (an increase in the proportion of the population at working age, due to a decrease in the birth rate and a small number of people who survived to old age), and finally, the period of ageing of the age structure in conditions of stabilization of the regime of population reproduction.

The stage of population rejuvenation in Kyrgyzstan ended in the 1970s; the «demographic window» for the development of the republic's economy remained open until the early $2010 \mathrm{~s}$ (Fig. 11). At this time, there was a simultaneous decrease in the proportion of children, adolescents, and the elderly (of retirement age). Since the mid-2010s the population of the republic enters the initial phase of population ageing, which, with other conditions unchanged, will last about 50 years. During this period, the proportion of the elderly will increase, and the proportion of children and adolescents will decrease at the same rate.

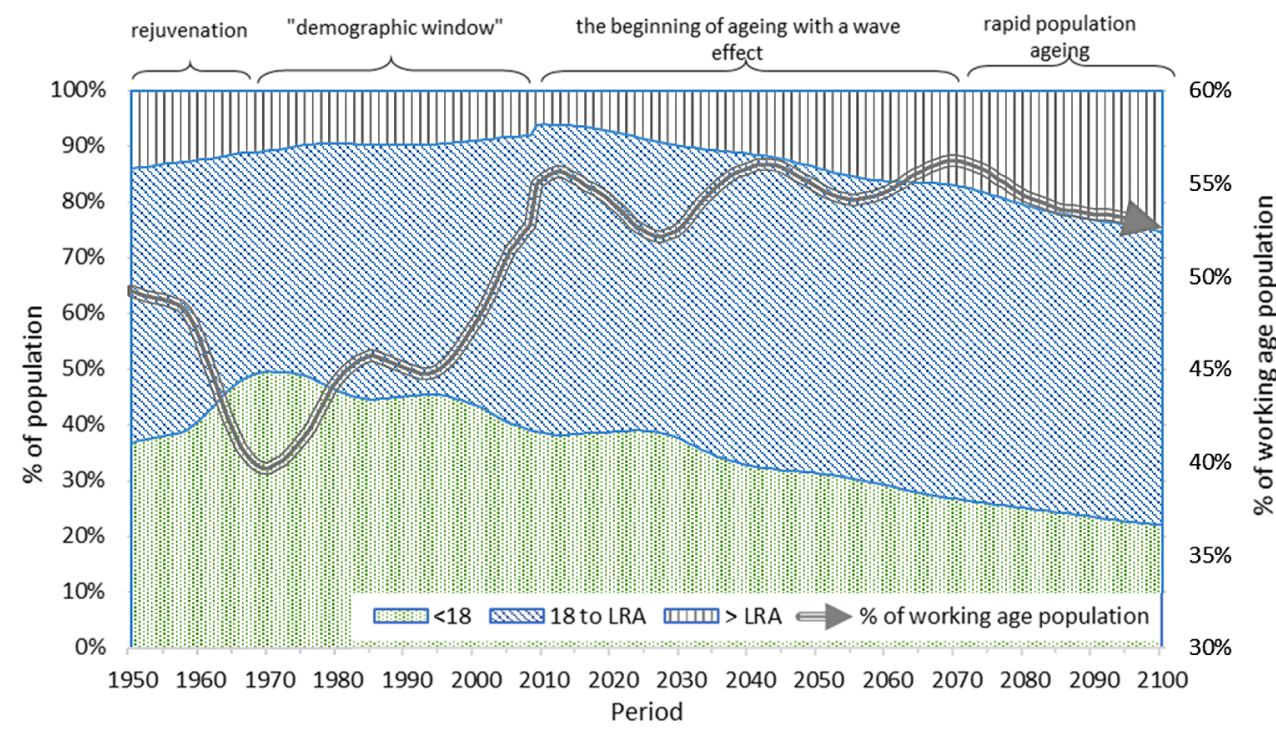

Fig. 11. Dynamics of the ratio of the main age groups of the population of the Kyrgyz Republic during the demographic transition from 1950 to 2020 and the outlook to 2100 as projected by the UN (2019 revision, medium version). Source: (United Nations, 2019). Note: LRA — legal retirement age

By the end of the 2050s the population of Kyrgyzstan will enter a state of demographic old age, which means that the population older than the reproductive age becomes more numerous than the population younger than the reproductive age, that is, the top of the demographic pyramid becomes wider than its base.

\section{Regional features of the population dynamics in the Kyrgyz Republic}

Over the past 5 years, the population has increased not only in the republic as a whole, but also in all regions, administrative districts and cities of republican significance. Most notable, 
by $13.3 \%$, was the increase in the population of the city of Osh. Remarkably, the highest population growth rates are observed in the zones of its greatest concentration, namely in the Chuy oblast and along the border of the Fergana Valley. It can be said that the fastest-growing population was in the most populous areas. The slowest rate of population growth was in the south-east and centre, in high-mountain regions with a low population: Ak-Talin, At-Bashyn and Zhumgal districts of Naryn oblast, and Ton district of Issyk-Kul oblast. In these territories, the population increase ranged from 2 to $4.5 \%$ in $2015-2020$.

In all administrative territories, the main component of population growth over the past 5 years was the excess of the number of births over the number of deaths, or natural population growth (Fig. 12). The leading positions in this indicator were occupied by the city of Osh, the Chon-Alai district of the Osh oblast and the Batken district of the Batken oblast, whose population increased by $14-15 \%$ over 5 years. Natural population growth was no less significant, over $10 \%$, in the Kadamjai district of the Batken oblast, in the districts adjacent to the city of Osh, and in the Suzak and Bazar-Korgon districts of the Jalal-Abad oblast.

It should be noted that in areas of high concentration of the population, including the city of Bishkek, the natural increase was also quite large. On the contrary, the lowest natural increase was found in the least populated rural areas of the Naryn and Issyk-Kul oblasts, as well as in a number of districts of the Chuy and Talas oblasts. This situation also looks somewhat unusual, since, as shown by the data of the Multiple Indicator Cluster Survey 2018 (MICS-18), residents of Chuy oblast, cities of Bishkek and Osh on average have fewer children than residents of other territories. It cannot be ruled out that the inconsistency between the data of state statistics and population surveys is due to the practice of registering births not at the place of residence (registration) of the mother, but at the place of birth without subsequent redirection of the act of birth. Thus, there is a threat that in state statistics data on population movement is replaced by data on the work of territorial bodies for registration of acts of civil status. In other words, under these conditions, all indicators of population movement (fertility, mortality, infant mortality, population changes), which are calculated in the territorial context, turn into statistical fiction and become useless for the needs of public administration and development planning ${ }^{1}$.

International migration and internal mobility play the most important role in shaping the dynamics of the population of districts and regions of the Kyrgyz Republic. Over the past 5 years, a positive migration balance was noted only in the cities of Bishkek and Osh, as well as in the Alamudun, Sokoluk, Moscow and Zhayilk districts of Chuy oblast adjacent to Bishkek. The smallest migration losses were incurred by the areas located in the zone of high concentration of the population: the «fertile crescent» adjacent to the Fergana Valley and the border areas of the Chuy oblast: Panfilovskiy, Chuyskiy and IssykAtinskiy (Fig. 13).

1 The Law on Acts of Civil Status of the Kyrgyz Republic of April 12, 2005 No. 60 provided for the possibility of registering acts at the place of occurrence of an event (birth, death) or at the place of residence (parents of a child, deceased), but without specifying the selection criteria, as well as the mechanisms and principles of interaction between civil registration authorities and state statistics. The new Law on Acts of Civil Status of the Kyrgyz Republic No. 110 of August 1, 2020 states (Article 11, paragraph 4) that «the civil registration authorities report to the statistics bodies of the Kyrgyz Republic information on state registration of birth, conclusion and dissolution of marriage and death", but at the same time it is established that territorially registered events are tied to the "place of application" (Articles 15, 21, and 32), which makes it even more problematic to compile statistics on the movement of the population in the territorial context. 


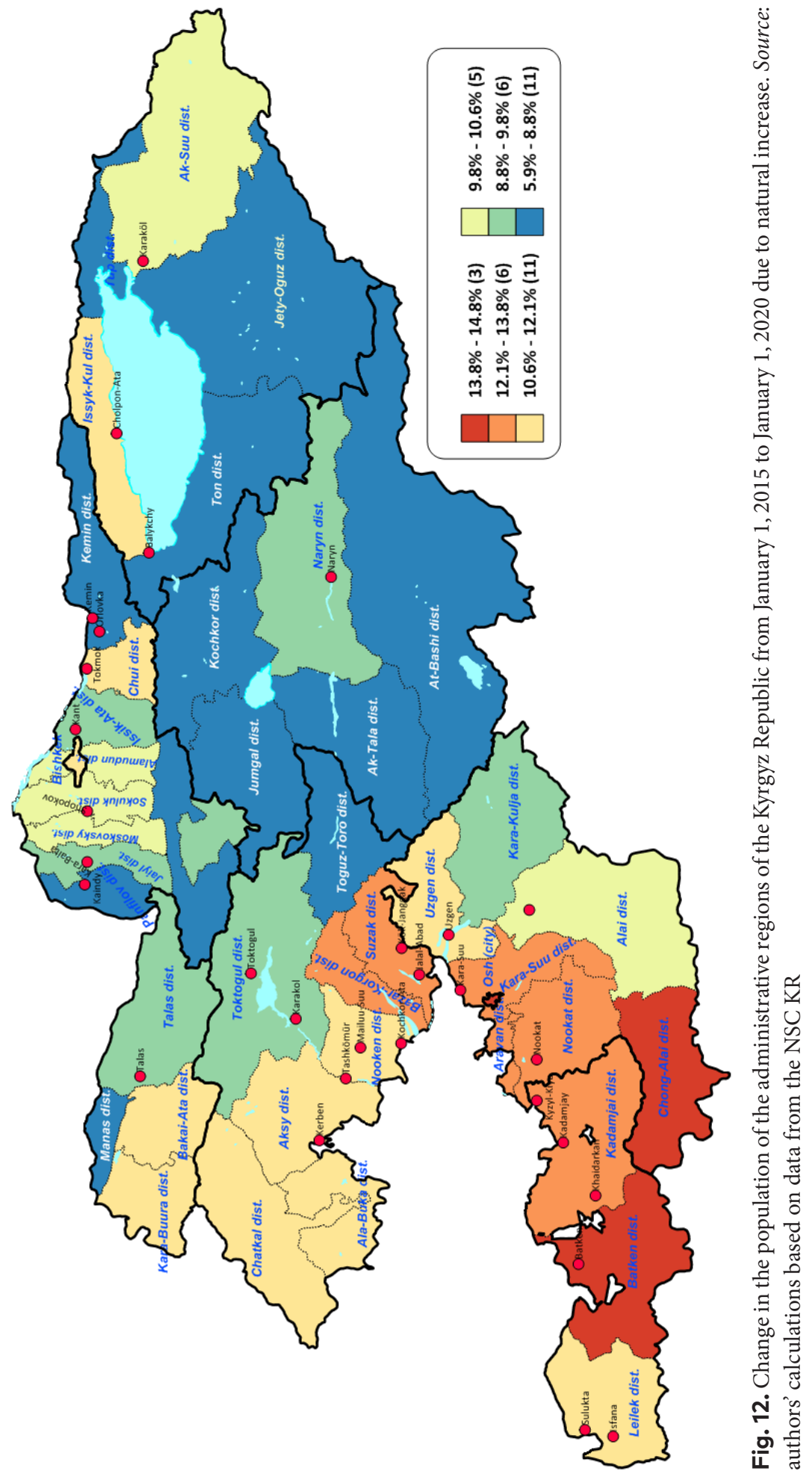




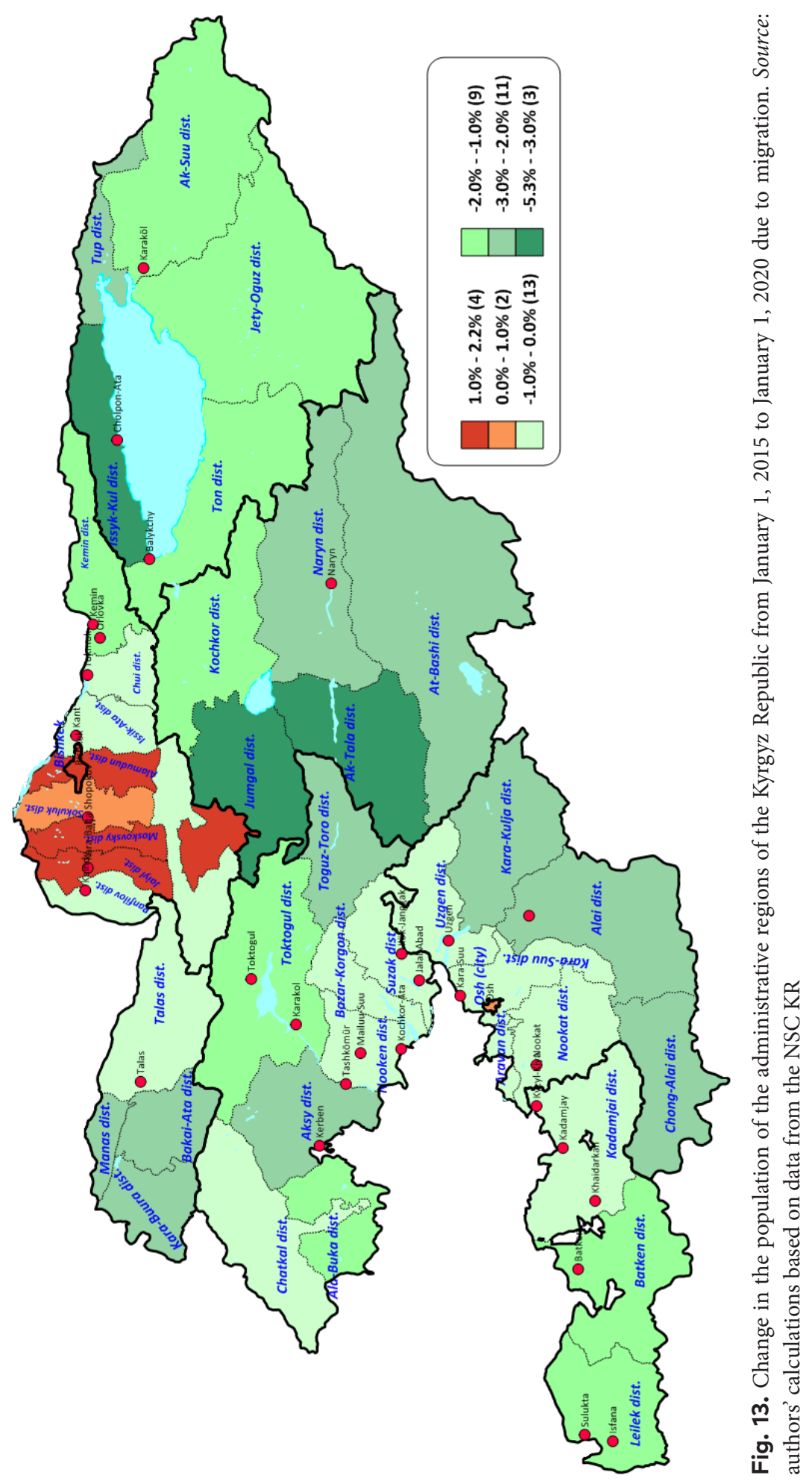


The latest data on interregional migration flows (migration exchange matrix) were obtained based on the results of the 2009 census. They showed with sufficient evidence that the main migration flows from all regions were oriented towards two cities of republican significance. Moreover, the most numerous flows were directed to Bishkek from the Naryn and Issyk-Kul regions. Less saturated flows are directed to the capital from the Jalal-Abad and Talas regions (Fig. 14). It is important to note that the volume of migration flows towards the capital is disproportionate to the population of regions sending migrants. Within the framework of the capital's migration system in all directions, the volumes of inbound flows far exceeded the volumes of outbound flows along the same exchange line.

A special migration subsystem, within the framework of which a very intensive mutual exchange of population took place, is the city of Osh and the Osh oblast. In 2004-2008, about $40 \%$ of those leaving the cities and rural areas of Osh oblast went to the city of Osh and only $35 \%$ to Bishkek and Chuy oblast. At the same time, for every two arrivals in the city of Osh from the region, there was one who had left the city for the region.

The migration exchange between Bishkek and Chuy oblasts had a completely different polarity, where between 2004 and 2009 for one person who moved from the region to the capital, there were two who had left the capital for the region. It is possible that an important role here is played by the availability of transport and the road network, which allows increasing the distance between the place of residence and the place of work.

Change of place of residence within the boundaries of one region is the second most important subsystem of internal migration of the population of the Kyrgyz Republic. At the same time, it seems that the volume of intraregional migration largely depends on the number of urban settlements and the size of the urban population. Thus, the largest relative volume of intraregional migration (the number of those who moved within the boundaries of the region in relation to the number of those leaving their permanent place of residence) was in the Jalal-Abad, Issyk-Kul and Chuy oblasts, and the smallest in the Naryn and Osh oblast (Fig. 15).

The intensity of migration flows (volume of migration exchange) between the regions of the republic (excluding the cities of Bishkek and Osh) was and remains insignificant (Fig. 16). In this subsystem, the centres of gravity were located in the Chuy and Osh oblasts. An important factor in the migration exchange between regions is their geographic proximity. Thus, the Batken and Jalal-Abad oblasts have closer ties with the Osh oblast, and the Talas, Issyk-Kul and Naryn oblasts - with the Chuy oblast.

Attempts made by Kyrgyz researchers to explain the specifics of interregional migrations by the prestige of a particular region (Matkerimova 2017) generally confirm our conclusions. A survey conducted in 2016 showed that the Chuy oblast is the most attractive for living, and the Osh oblast is third. The respondents ranked the Issyk-Kul oblast second; according to the author, this is partly due to the economic opportunities, even seasonal, that the tourism industry provides in this region. At the same time, ranking the Chuy oblast first on the scale of prestige, the respondents almost always ranked the region in which they lived at the time of the survey second or third. However, the answer to the question about where the respondents would like to live shows that over $70 \%$ would choose the cities of the Chuy oblast or their suburbs; most likely, it was mainly about Bishkek (Matkerimova 2017: 97, 99). 


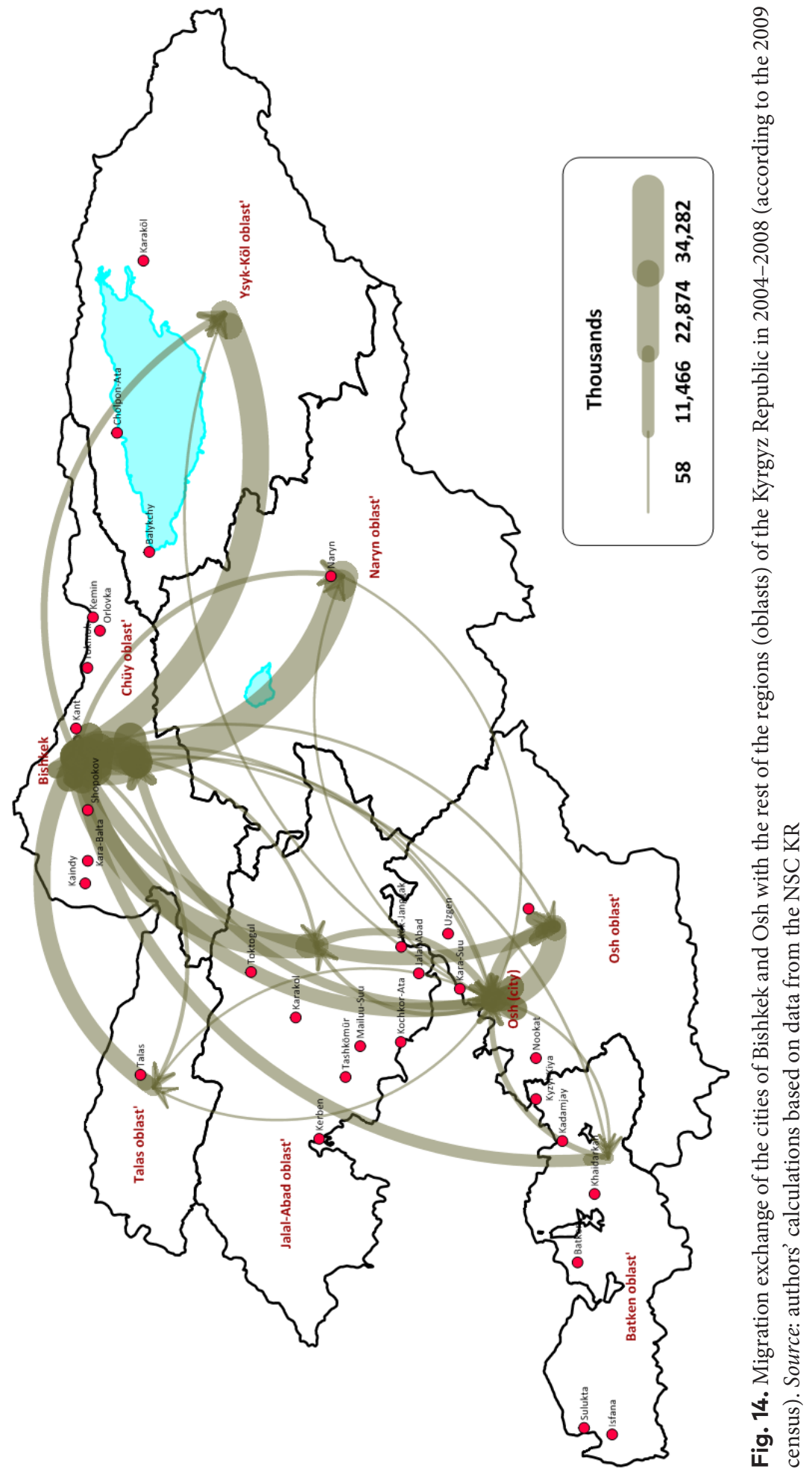




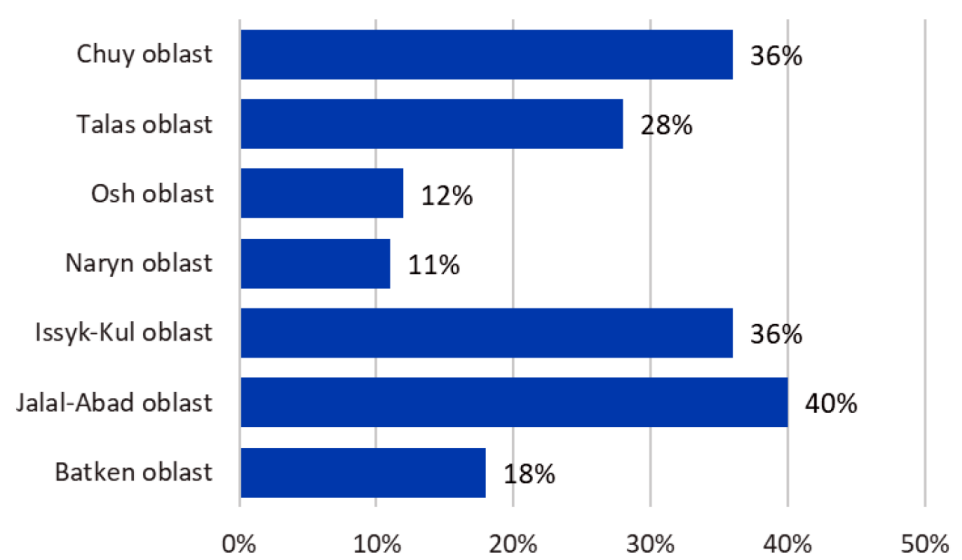

Fig. 15. Share of those who changed their place of residence within the boundaries of one region among all those leaving in 2004-2008. Source: authors' calculations based on data from the NSC KR.

Even though the data of the 2009 census are certainly outdated, one can reasonably believe that, in general, the relevance of the described system of internal migration remains to this day. As shown by the data of the MICS-2018 survey, according to which, however, it is possible to judge only the migration behaviour of women who were aged 15-49 at the time of the survey, intraregional migration and migration towards the two largest cities remain the main components of the migration system (Cluster survey... 2019), at least for this category of respondents (table 2).

Table 2. Estimation of the main directions of internal migration among women aged 15-49 according to MICS-18 data in the Kyrgyz Republic (weighted data).

\begin{tabular}{|c|c|c|c|c|}
\hline \multirow[t]{2}{*}{$\begin{array}{l}\text { Previous place } \\
\text { of residence }\end{array}$} & \multicolumn{2}{|c|}{$\begin{array}{l}\text { Share of those who left for Bish- } \\
\text { kek or who changed their place } \\
\text { of residence within the region, } \\
\text { by the place of departure, } \%{ }^{*}\end{array}$} & \multirow[t]{2}{*}{$\begin{array}{l}\text { Current place } \\
\text { of residence }\end{array}$} & \multirow{2}{*}{$\begin{array}{l}\text { Share of migrants } \\
\text { (not residents } \\
\text { since birth) among } \\
\text { those surveyed, by } \\
\text { the current place } \\
\left.\text { of residence, } \%{ }^{* *}\right)\end{array}$} \\
\hline & to Bishkek & within the region & & \\
\hline Bishkek & - & 19 & Bishkek & 59 \\
\hline Osh & 43 & 16 & Osh & 30 \\
\hline Batken oblast & 21 & 71 & Batken oblast & 11 \\
\hline Jalal-Abad oblast & 11 & 80 & Jalal-Abad oblast & 8 \\
\hline Issyk-Kul oblast & 32 & 56 & Issyk-Kul oblast & 13 \\
\hline Naryn oblast & 50 & 37 & Naryn oblast & 22 \\
\hline Osh oblast & 22 & 53 & Osh oblast & 9 \\
\hline Talas oblast & 24 & 68 & Talas oblast & 10 \\
\hline Chuy oblast & 33 & 63 & Chuy oblast & 39 \\
\hline
\end{tabular}

Source: authors' calculations based on the MICS-2018 data (https://mics.unicef.org/surveys).

Notes: ${ }^{\star}$ all migrants $=100 \% ;{ }^{* *}$ all respondents $=100 \%$ 


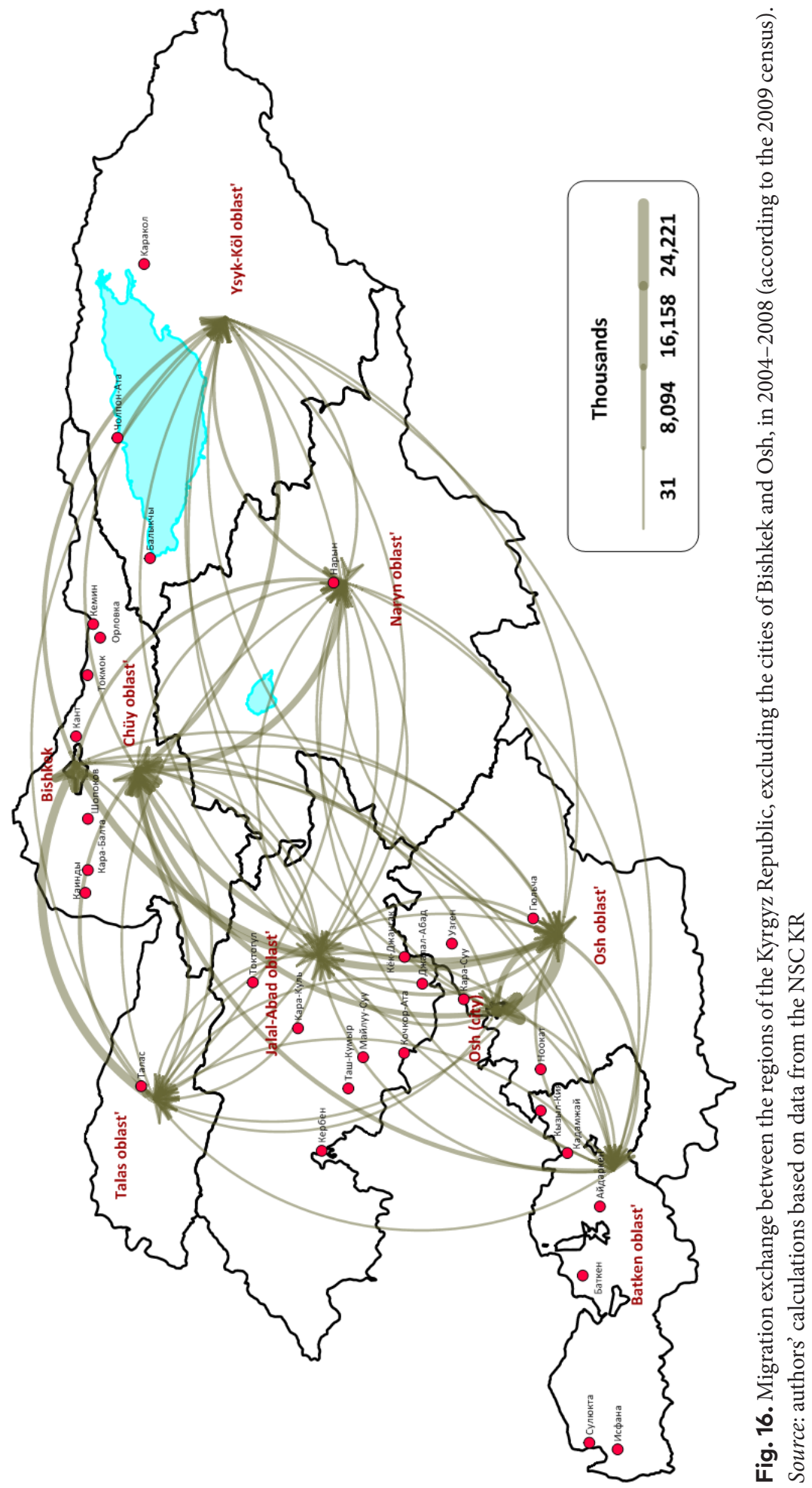


In addition, MICS-2018 data enable estimating the age profile of internal migration (Fig. 17). Thus, the average age of women leaving rural settlements is 20.7 years (including to another rural settlement), leaving small and medium-sized cities -21.3 years, and the average age of women moving out from large cities is 23.8 years.

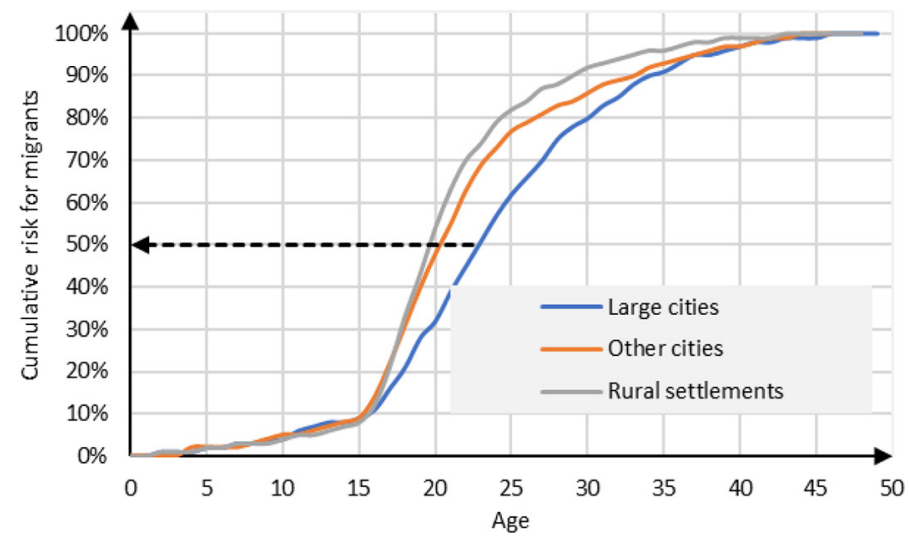

Fig. 17. Distribution (cumulative total) of women who arrived at the last place of residence as of the date of the survey by age, depending on the type of settlement they left. Source: authors' calculations based on MICS-2018 data. Note: The analysis was carried out on the basis of answers to the questions asked in the framework of the MICS-2018 survey: age at the time of the survey, the length of residence at the survey site and the type of settlement from which the interviewee came. An example of reading the graph: $82 \%$ of the total number of women who came to their last place of residence from the countryside had left their previous place of residence before reaching the age of 25.

Unfortunately, the MICS-2018 data do not allow tracing the entire migration trajectory, which can start in rural areas, then lead from a small town to a medium one, and end in a big city; also, the research data do not provide an opportunity to judge the motives of migration. Given that only women were interviewed, the reason for moving to another locality could be marriage, but also leaving to study or to seek employment immediately after graduating from secondary education. Nevertheless, an important conclusion that can be drawn from this analysis is this: migration activity increases very rapidly when girls reach the age of 15 , regardless of the type of settlement, and practically comes to an end upon reaching the age of 30 for those moving from rural areas and at 33-35 years for those moving from small and large cities, respectively.

\section{Urbanization}

Taking into account that the most likely motives for both external and internal migration are training (acquisition of a profession) and job search, it must be admitted that large cities with a developed educational network and an extensive labour market are becoming natural poles of attraction of migration flows.

As official statistics show, the level of urbanization in the Kyrgyz Republic is rather low. According to estimates at the beginning of 2020, the share of the urban population does not exceed $35 \%$ of the population of the republic (Fig. 18). 


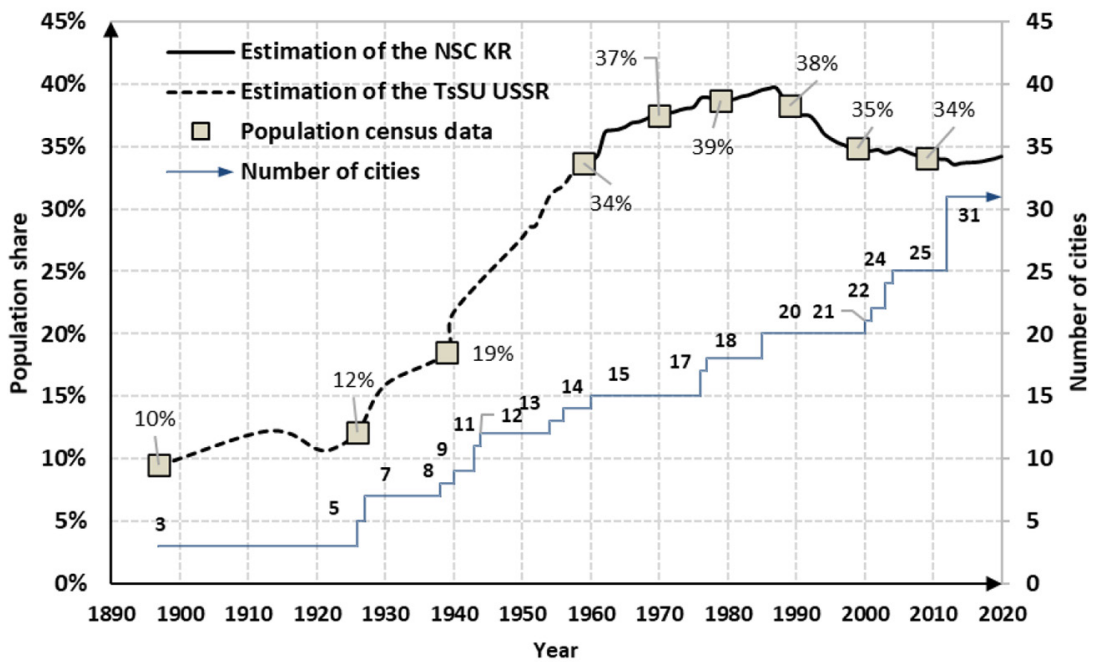

Fig. 18. Dynamics of the share of the urban population and the growth in the number of urban settlements in Kyrgyzstan since the beginning of the 20th century. Source: Census data for 1897, 1926, 1939, 1959, 1970, 1979, 1989, 2009

At the same time, the concentration of the urban population is extremely high. Bishkek alone, the number of inhabitants of which has already exceeded one million people, is home to $49 \%$ of the urban population. Another $12 \%$ of the urban population of the republic is concentrated in the city of Osh with a population of about 264 thousand people. Next in line is the city of Jalal-Abad, a regional centre with a population of just over 100 thousand people. Of other regional centres, the population exceeds 50 thousand people only in the cities of Karakol (Issyk-Kul oblast, 77 thousand inhabitants) and Tokmok (Chuy oblast, 65 thousand inhabitants). All this suggests that weak urbanization is an important, if not the main reason for the concentration of the population in and around the cities of Bishkek and Osh.

The concentration of the population around the two republican metropolises (Bishkek and Osh) poses serious threats to the deterioration of the ecological situation and the reduction of agricultural territories. For example, today in the Chuy oblast $44 \%$ of grain and $94 \%$ of sugar beet production are concentrated, and the use of land for other purposes has a negative impact on the volume of production in the agricultural sector.

Another threat is associated with the practice of cottage construction, which is widespread in the expanding areas of urban development (Fig. 19) and leads to inefficient use and rapid degradation of urban infrastructure (access to roads, sewerage, power supply; see Adieva and Zhumaliev, 2016: 17, 19-20; Matkerimova 2014: 87).

In the Kyrgyz Republic, the ratio between the urban and rural population, calculated according to official data, does not at all correspond to the level of economic development and the structure of production. According to the latest data, in 2014 only $31.6 \%$ of all employed in the economy of the republic worked in agriculture (including forestry and fishing), and by 2018 this share had progressively decreased to $20.3 \%$ (Statistical Yearbook... 2019: table 5.6). According to the data of the integrated population survey of household budgets and labour force, the share of employed in the agricultural sector of the economy was $18 \%$. These data suggest that the actual level of urbanization in the Kyrgyz Republic is significantly higher than the official statistics indicate. 

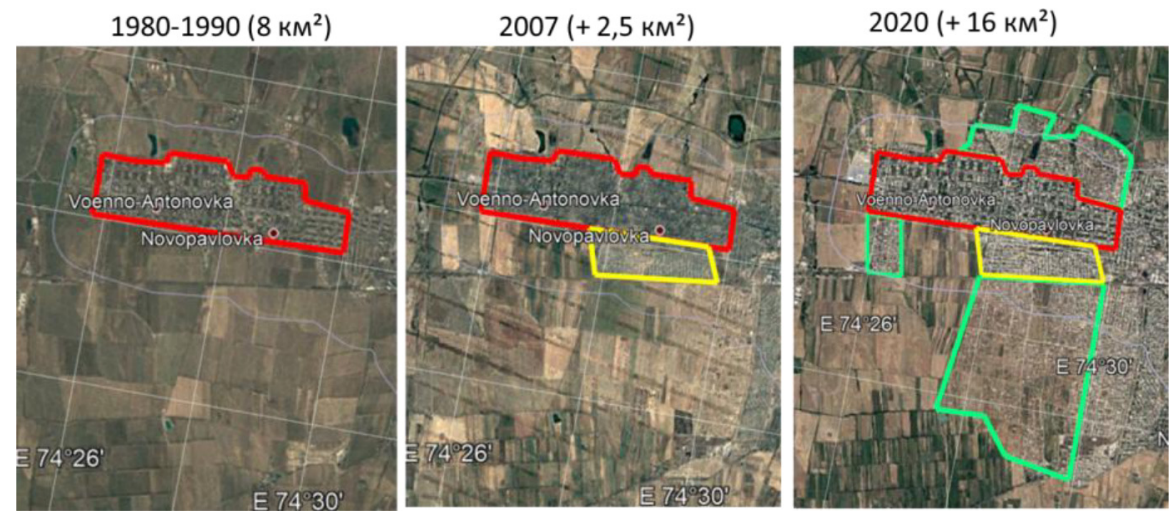

Fig. 19. Expansion of the residential area through the occupation of agricultural land in the eastern part of Bishkek between 1980 and 2020. Source: compiled by the authors using the Google Earth Pro archive

\section{Conclusion}

An analysis of the current dynamics and prospects of movement of the population of the Kyrgyz Republic shows the presence of a complex of interrelated problems and challenges caused by the rapid growth of the population and changes in its age structure, and the key ones among them are:

- mass departure of the working age population, especially young people, abroad to work (labour migration),

- increasing number of population of retirement age,

- peculiarities of settlement with the concentration of the population around the two largest urban agglomerations of the republic, the cities of Bishkek and Osh.

Solving these problems requires a systematic approach and political decision-making. First of all, a large-scale assessment of the impact of labour migration on the national economy, on the level of well-being of the population, and on the formation of the state budget and the quality of labour resources of the republic is necessary. For this, it is necessary to develop and improve the system for monitoring external and internal migration flows, to conduct special population surveys, including within the framework of the general population census. It is especially important to develop a strategy and tactics for harmonizing the economy of national institutions of social support (education, health care, and pensions) and the economy of international labour migration within the EAEU and bilateral interstate relations on the legal regulation of the use of foreign labour.

The inevitable growth of the population of older age primarily poses the problem of financial security to the state, which is responsible for the payment of pensions, the total volume of which, other things being equal, will grow in proportion to the increase in the number of people who have reached retirement age. But if over the next 10 years the population of retirement age in the Kyrgyz Republic increases by about $40 \%$, then the population aged from 20 years old up to the official retirement age will increase by only $5 \%$. Taking into account the difference in the reference base (the number of the corresponding contingents), it can be argued that if today in the republic there are 10 soms of wages per 1 som of pension payments, then in ten years, other things being equal, this ratio will already be 6 to 1 . The problem is aggravated by the fact that the number of people employed in the national econ- 
omy of the republic is much less than the number of the population at working age (from 20 years to the official retirement age), and the number of pensioners, taking into account privileged categories, is practically in the same proportion greater than the number of people who have reached retirement age. According to the National Statistical Committee, in 2018 the number of employed in the country's economy was $28 \%$ less than men aged 20-62 together with women aged 20-57 (2.38 million versus 3.31 million), and the number of pensioners is 39\% higher than those of retirement age (695 thousand versus 499 thousand). In this situation, it can be assumed that if a decrease in the outflow of labour resources from the republic was achieved through the creation of new jobs in the national economy, this could not only provide additional resources for replenishing the pension fund, but also create conditions for the growth of incomes of the population, and therefore, for increased consumption and economic growth in general. Perhaps, in the future, the problem of pension provision in Kyrgyzstan will be mitigated thanks to the Agreement on the Provision of Pensions for Workers of the EAEU Member States, which entered into force in 2021 and gives the right to pension payments to Kyrgyz citizens who legally worked in Russia (Agreement..., 2020).

The concentration of the population in the urban agglomerations of Bishkek, Osh and JalalAbad undoubtedly creates tension in the ecological situation and a threat of a decrease in the area of agricultural land. But at the same time, an increase in demand for housing opens up wide opportunities for the implementation of urbanization programmes and infrastructure projects, which will, in turn, contribute to the creation of new jobs, sewage construction and maintenance in the urban environment and, ultimately, an increase in the standard of living of the population.

\section{Reference list}

Adieva R.N., Zhumaliev N.E. (2016) The impact of internal migration of the population on the ecological picture of the city of Bishkek // Ecological and technosphere safety of mining regions. Proceedings of the IV International Scientific and Practical Conference: 14-21. URL: https://www.elibrary. ru/download/elibrary_26343475_40100839.pdf.

Chudinovskikh O.S., Stepanova A.V. (2020) On the quality of federal statistical observation of migration processes // Demographic Review: 7 (1): 54-82. https://doi.org/10.17323/demreview. v7i1.10820.

Dzhusupbekov A.K., Shamshibaev M.M. (2017) External and internal migration in the Kyrgyz Republic // Bulletin of the Institute of Philosophy and Political and Legal Research of the National Academy of Sciences of the Kyrgyz Republic: 1: 71-75. URL: https://www.elibrary.ru/download/ elibrary_30476369_26763436.pdf

Matkerimova G.T. (2014) On the issue of internal migration in the labour market of the Kyrgyz Republic // Bulletin of the universities of Kyrgyzstan: 11: 86-88. URL: http://www.science-journal.kg/ media/Papers/ivk/2014/11/ivk-2014-N11-86-88.pdf.pdf.

Matkerimova G.T. (2017) Analysis of the prestige of the regions of Kyrgyzstan // Innovative economy and society: 4(18): 96-101. URL: https://www.elibrary.ru/download/elibrary_32490129_68927590.pdf.

Multiple indicators cluster survey. Kyrgyz Republic 2018. (2019) Survey report. Bishkek, Kyrgyz Republic: National Statistical Committee of the Kyrgyz Republic, United Nations Children's Fund (UNICEF). URL: https://mics-surveys-prod.s3.amazonaws.com/MICS6/Europe\%20 
and $\% 20$ Central\%20Asia/Kyrgyzstan/2018/Survey\%20findings/Kyrgyzstan\%20MICS\%20 2018_Russian.pdf.

Population of Kyrgyzstan at the beginning of the XXI century. (2011) M.B. Denisenko (ed.). United Nations Population Fund in the Kyrgyz Republic. Bishkek. ( https://kyrgyzstan.unfpa.org/en/ node/7262).

Population of Kyrgyzstan. (2004) Z. Kudabaeva, M. Guillot, M. Denisenko (ed.). Bishkek: National Statistical Committee of the Kyrgyz Republic.

Sheyitov K.T. (2018) Analysis and assessment of external and internal interregional migration flow in Kyrgyzstan // Bulleting of universities of Kyrgyzstan: 7: 40-43. URL: http://www.science-journal. kg/media/Papers/ivk/2018/7/40-43.pdf.

Sievert S., Zakharov S.V., Klingholz R. The Vanishing World Power. The demographic future of Russia and other former Soviet states / Trans. from German: Yu. Strauch; scientific. ed.: S.V. Zakharov. Berlin: Berlin Institute for Population and Development, 2011.

\section{Other data sources}

Devision database of the Laboratory of Demography and Popular Economics, Faculty of Economics, Lomonosov Moscow State University. URL: https://devision-dmo.econ.msu.ru.

All-Union census of December 17, 1926: brief summaries (1927). Issue. 3: Population of the USSR; Issue 4: Nationality and native language of the population of the USSR, M .: CSD of the USSR.

Demographic Yearbooks of the Kyrgyz Republic, 2008-2012, 2009-2013, 2010-2014, 2011-2015, 20122016, 2013-2017, 2014-2018 and 2015-2019, Bishkek: National Statistical Committee of the Kyrgyz Republic. URL: Demographic Yearbook of the Kyrgyz Republic - Archive of Publications - Statistics of Kyrgyzstan (stat.kg)

Demographic Yearbook of the USSR 1990 (1990) M.: Finance and Statistics, 1990.

Population of the USSR 1973 (1975) Statistical Yearbook. Moscow: Finance and Statistics.

Population of the USSR 1988 (1989) Statistical Yearbook. Moscow: Finance and Statistics.

The first Russian Imperial Census (1905) N.A. Troinitsky. (ed.), Volume 85, Semirechenskaya Oblast, St. Petersburg: Central Statistical Committee of the Ministry of Internal Affairs.

Statistical Yearbook of the Kyrgyz Republic, 2014-2018 (2019) Table 5.6 "Average annual number of people employed in the economy by type of economic activity", Bishkek: National Statistical Committee of the Kyrgyz Republic. URL: Statistical yearbook of the Kyrgyz Republic - Archive of Publications - Statistics of Kyrgyzstan (stat.kg)

Federal Law No. 354-FL (2020) Agreement on Pension Provisions for Workers of the Eurasian Economic Union Member States. URL: Agreement on Pension Provisions for Workers of the Eurasian Economic Union Member States - docs.cntd.ru

United Nations (2019) Probabilistic Population Projections based on the World Population Prospects: The 2019 Revision. Department of Economic and Social Affairs, Population Division, DESA. http:// esa.un.org/unpd/wpp/

\section{Information about the authors}

- Avdeev Alexandre Alexandrovich, Cand. Sci. (Econ.), Head of the Sector of the Laboratory of Population Economics and Demography, Faculty of Economics, Lomonosov 
Moscow State University; Professor at the Institute of Demography, University Paris 1 Pantheon-Sorbonne. E-mail: Alexandre.Avdeev@univ-paris1.fr

- Troitskaya Irina Alekseevna, Cand. Sci. (Econ.), Head Researcher, Laboratory of Population Economics and Demography, Faculty of Economics, Lomonosov Moscow State University. E-mail: itro@econ.msu.ru 